\title{
Inhibition of the Activation of Hageman Factor (Factor XII) by Peripheral Blood Cells
}

Oscar D. Ratnoff, Marlene M. Emanuelson, and Nicholas P. Ziats

Departments of Medicine and Pathology, Case Western Reserve University School of Medicine, and University Hospitals of Cleveland, Cleveland, Ohio 44106

\begin{abstract}
Suspensions of peripheral blood mononuclear cells (PBMC), monocytes, T or B lymphocytes, platelets or granulocytes, and cell-depleted supernatant fluids of these suspensions inhibited activation of Hageman factor (HF, Factor XII) by ellagic acid, a property not shared by erythrocytes. PBMC also inhibited HF activation by glass or sulfatides. Contaminating platelets may have contributed to inhibition by PBMC.

Elaboration of agents inhibiting HF activation required metabolically active cells. The inhibitor(s) in PBMC supernates were not identified with known agents, but had properties of a nonenzymatic protein. PBMC supernates did not contain fibrinogen, nor alter the thrombin, prothrombin, or partial thromboplastin times of normal plasma, amidolysis by activated plasma thromboplastin antecedent (Factor XIa) or activated Stuart factor (Factor Xa) or esterolysis by $\mathbf{C} \overline{\mathbf{I}}$ (C1 esterase); they inhibited plasmin minimally.

These experiments suggest that peripheral blood cells may impede intravascular coagulation. Whether this property helps maintain the fluidity of blood is unclear.
\end{abstract}

\section{Introduction}

A variety of devices appear to maintain the fluidity of circulating blood. Among these are a multitude of plasma proteins that inhibit the enzymatically active forms of clotting factors or, under suitable circumstances, digest procoagulant proteins or the fibrin clot itself. The experiments to be described suggest that another class of substances may deter the formation of intravascular clots. Suspensions of peripheral blood mononuclear cells, granulocytes, and platelets all appear to inhibit the activation of Hageman factor ( $\mathrm{HF},{ }^{1}$ Factor XII). The responsi-

Address reprint requests to Dr. Ratnoff, Department of Medicine, University Hospitals of Cleveland, 2074 Abington Road, Cleveland, OH 44106.

Received for publication 27 October 1986 and in revised form 25 March 1987.

1. Abbreviations used in this paper: BS, barbital-saline buffer; BS-Alb, BS containing $0.25 \%$ bovine albumin; $C \overline{1}, C l$ esterase, activated form of the first component of complement; $\mathrm{C} \overline{1}-\mathrm{INH}, \mathrm{Cl}$ esterase inhibitor, $\mathrm{Clq}$, the Clq subcomponent of the first component of complement; DFP, diisopropylfluorophosphate; DPBS, Dulbecco's phosphate-buffered saline; DPBS-CaMg, Dulbecco's phosphate-buffered saline without calcium and magnesium ions; HF, Hageman factor, Factor XII; HPPAN, H-D-prolyl-L-phenylalanyl-L-arginine $p$-nitroanilide hydrochloride (S2302); LBTI, lima bean trypsin inhibitor; PF4, platelet factor 4; $p$-NA, p-nitroaniline; PTA, plasma thromboplastin antecedent (Factor XI); SBTI, soybean trypsin inhibitor; S2222, benzoyl-isoleucyl-glutamyl-glycyl-arginine $p$-nitroanilide; S2238, H-D-phenylalanylpipecolyl-arginine- $p$-nitroanilide.

J. Clin. Invest.

(c) The American Society for Clinical Investigation, Inc.

$0021-9738 / 87 / 10 / 1180 / 10 \$ 2.00$

Volume 80, October 1987, 1180-1189 ble agent or agents are detected in cell-depleted supernatant fluid separated from cell suspensions. The inhibitory properties are associated with proteins that are synthesized by the cells. The biological significance of the inhibitory agent or agents in deterring intravascular coagulation remains to be determined.

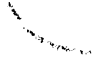

\section{Methods}

Heparinized blood was prepared by drawing $50 \mathrm{ml}$ blood from the antecubital vein of human subjects into polypropylene syringes containing $1 \mathrm{ml}$ heparin $(1,000 \mathrm{NIH} \mathrm{U} / \mathrm{ml})$; the donors were normal adults except for a 19-yr-old woman with idiopathic aplastic anemia $(5,000$ platelets $/ \mu \mathrm{l})$. Citrated blood was prepared by transferring $10 \mathrm{ml}$ normal venous blood, drawn into a polypropylene syringe, to a polystyrene centrifuge tube containing $0.2 \mathrm{ml}$ sodium citrate buffer $(0.5 \mathrm{M}, \mathrm{pH}$ 5.0). Human AB serum was separated from venous blood of fasted donors that was incubated overnight in glass at $37^{\circ} \mathrm{C}$. Pooled normal plasma, arbitrarily said to contain $1.00 \mathrm{U} \mathrm{HF} / \mathrm{ml}$, was prepared from the venous blood of 24 normal men aged 21 to $40 \mathrm{yr}$ and stored at $-70^{\circ} \mathrm{C}(1)$. Informed consent was obtained from all subjects.

HF (Factor XII) was purified by two different methods (2, 3), and was devoid of other clotting factors and plasminogen. It displayed a single band upon unreduced or reduced polyacrylamide gel electrophoresis. Before use, $\mathrm{HF}$ was diluted, usually to $0.05 \mathrm{U} / \mathrm{ml}$, in $0.25 \%$ bovine serum albumin in barbital-saline buffer (BS-Alb).

Apparent solutions of $10^{-4} \mathrm{M}$ ellagic acid (synthesized by Dr. James Crum in 1966 or Dr. Miklos Bodanszky in 1983, Case Western Reserve University) in BS were prepared as described earlier (2) and diluted to the desired concentration with BS.

The buffers used included BS (2), BS-Alb, tris-imidazole-saline buffer (0.025 M, pH 8.2) (4), Dulbecco's phosphate-buffered saline (DPBS) or DPBS without calcium and magnesium ions (DPBS-CaMg) (MA Bioproducts, Walkersville, MD; KC Biological, Lenexa, KA; or Gibco, Grand Island, NY) (5), DPBS with $1 \%$ bovine albumin (DPBSAlb), RPMI 1640 with 2 mM L-glutamine (RPMI)(6), RPMI with 10\% human AB serum (RPMI-HS), and RPMI with $10 \%$ fetal bovine serum (RPMI-FBS) (MA Bioproducts).

Sheep erythrocytes, suspended in Alsever's solution, were sedimented at $1,800 \mathrm{~g}$ at $10^{\circ} \mathrm{C}$, washed three times with RPMI and suspended at a concentration of $1 \%(\mathrm{vol} / \mathrm{vol})$ in RPMI.

FBS (Sterile Systems, Logan, UT) was heated at $56^{\circ} \mathrm{C}$ for $30 \mathrm{~min}$ before use.

H-D-prolyl-L-phenylalanyl-L-arginine p-nitroanilide dihydrochloride (HPPAN, S2302), benzoyl-isoleucine-glutamyl-glycyl-arginine p-nitroanilide (S2222), H-D-valyl-L-leucyl-L-lysine p-nitroanilide (S2251), and H-D-phenylalanyl-pipecolyl-arginine p-nitroanilide (S2238) were obtained from Helena Laboratories (Beaumont, TX), dissolved at a concentration of $1 \mathrm{mM}$ in distilled water, and stored at $4^{\circ} \mathrm{C}$. Before use, HPPAN and S2238 were diluted with an equal volume of Tris-imidazole-saline buffer. $N$-Acetyl-L-tyrosine ethyl ester (Calbiochem, La Jolla, CA) was dissolved at a concentration of $1 \mathrm{M}$ in ethyleneglycol monomethyl ester (Fisher Scientific, Fair Lawn, NJ).

Crude IgG fractions of normal goat and rabbit sera (Pel-Freez Biologicals, Rogers, AR), rabbit antiserum against human $\mathrm{Clq}$ (Boehringer-Mannheim Biochemicals, Houston, TX) and goat antiserum against $\beta_{2}$-glycoprotein-I (Calbiochem) were separated as de- 
scribed earlier $(7,8)$. Crude IgG fractions of normal goat and rabbit sera, goat antiserum against human platelet factor 4 (PF4; Atlantic Antibodies, Scarborough, ME) and rabbit antiserum against human Cì-INH (Cī inactivator, Behring Diagnostics, La Jolla, CA) were prepared in the same way and further purified by filtration through DEAE-Affigel Blue (Bio-Rad Laboratories, Richmond, CA) and concentrated, first by negative pressure dialysis against $\mathrm{BS}$ and then in a Centricon 30 microconcentrator (Amicon Corp., Danvers, MA).

Other reagents used included heparin (beef lung, $100 \mathrm{U} / \mathrm{ml}$, Upjohn Co., Kalamazoo, MI), Ficoll-Paque (Pharmacia Fine Chemicals, Piscataway, NJ), crystallized bovine serum albumin (BSA, Pentex, Miles Laboratories, Naperville, IL), bovine brain sulfatides (monogalactosyl-stearate, Supelco, Bellefonte, PA), bovine thrombin (Thrombostat, U. S. Pharmacopeia, Parke-Davis Co., Detroit, MI), and bovine trypsin (Worthington Biochemical Corp., Freehold, NJ). EDTA, lima bean trypsin inhibitor (LBTI), soybean trypsin inhibitor (SBTI), diisopropylfluorophosphate (DFP), benzamidine hydrochloride, cycloheximide and sodium azide were from Sigma Chemical Co., St. Louis, MO. Purified human Stuart factor (Factor X), activated by Russell's viper venom (Factor $\mathrm{Xa}$ ) (9) and purified human trypsin-activated plasma thromboplastin antecedent (activated PTA, Factor XIa) (10) were the gifts of Dr. L. T. Goodnough, Case Western Reserve University. PF4 was the gift of Dr. L. Culp, Case Western Reserve University (11). Cì (C1 esterase) was prepared as described by Donaldson (12). Crude soybean phosphatides (Centrolex "P," the gift of Central Soya Co., Fort Wayne, IN) were suspended at $0.1 \%$ in $0.15 \mathrm{M}$ sodium chloride.

Peripheral blood cells were separated by modifications of published methods, as described below. Before testing, the supernatant fluids of cell suspensions were filtered through Millex GV $0.22 \mu \mathrm{m}$ filters (Millipore Corp., Bedford, MA), as described below.

Peripheral blood mononuclear cells (PBMC) and the supernatant fluids of PBMC suspensions were prepared by an adaptation of Böyum's method (13). Typically, in replicate, $25 \mathrm{ml}$ heparinized blood was diluted with $25 \mathrm{ml}$ DPBS-CaMg. 10-ml aliquots were layered onto $3 \mathrm{ml}$ Ficoll-Paque, and centrifuged at $450 \mathrm{~g}$ for $45 \mathrm{~min}$. The PBMC layers were combined, washed twice with $40 \mathrm{ml}$ DPBS-CaMg, once with $40 \mathrm{ml}$ of an equal mixture of DPBS-CaMg and DPBS and once with $40 \mathrm{ml}$ of DPBS, pelleting the cells each time at $500 \mathrm{~g}$ for $10 \mathrm{~min}$. The washed cells, suspended in DPBS at $5 \times 10^{6} / \mathrm{ml}$, were recentrifuged in the same way. The mean viability of PBMC was $93 \%$ (SD $\pm 6.8 \%)$.

The supernatant fluid was filtered through a Millex GV $0.22-\mu \mathrm{m}$ filter unit attached to a polypropylene syringe, replacing the filter after $15 \mathrm{ml}$ had been filtered. The PBMC, resuspended at $5 \times 10^{6}$ cells $/ \mathrm{ml}$, and the filtered supernatant fluid were saved. No lactic dehydrogenase was detected in the PBMC supernate in a sample containing $15 \mu \mathrm{g}$ protein/ml, using a method sensitive to $1 \mathrm{U} / \mathrm{liter}$ (14). In some experiments, the cells were recentrifuged and resuspended repeatedly, saving successive supernatant fluids. PBMC and their supernates were tested within an hour of separation after storage in an ice-water bath.

Concentrates of the supernatant fluid of PBMC were prepared by negative pressure dialysis against DPBS, or by positive pressure filtration through an Amicon filter (ultrafiltration cell, model 8400, Amicon Corp.) fitted with a PM 10 membrane. Concentrates were made from the combined supernates of replicate preparations or from the combined supernates of successive washes of a single preparation of PBMC.

The possible presence of Cī-INH, Clq, $\beta_{2}$-glycoprotein-I or PF4 in concentrated PBMC supernatant fluid (1 $\mathrm{mg}$ protein $/ \mathrm{ml}$ ) was examined by immunodiffusion, using $1 \%$ agar (15). The presence of glycosaminoglycans containing uronic acid was tested by measuring the concentration of uronic acid in the same concentrate (16).

The suspensions of PBMC were contaminated with platelets. In some experiments, the proportion of platelets was reduced by $\sim 85-95 \%$ by centrifuging $25 \mathrm{ml}$ of heparinized blood at $200 \mathrm{~g}$ for 15 min. The platelet-rich supernate was removed, and the cells were washed three times with DPBS-CaMg, centrifuging at $200 \mathrm{~g}$. The platelet-depleted blood was used to prepare PBMC.
To test the effect of trypsin on the inhibitory properties of PBMC and PBMC supernate, $0.025 \mathrm{ml}$ bovine trypsin $(0.05 \mathrm{mg} / \mathrm{ml} \mathrm{BS})$ or BS was incubated with $0.1 \mathrm{ml} \mathrm{PBMC}$, supernate or DPBS at $37^{\circ} \mathrm{C}$ for $2 \mathrm{~h}$ in $12 \times 75 \mathrm{~mm}$ polystyrene tubes. Thereafter, $0.025 \mathrm{ml}$ LBTI $(0.2$ $\mathrm{mg} / \mathrm{ml} \mathrm{BS})$ and $0.05 \mathrm{ml} \mathrm{HF}(0.1 \mathrm{U} / \mathrm{ml}$ in $0.5 \% \mathrm{BS}-\mathrm{Alb})$ or BS-Alb alone, were added in rapid succession. After $10 \mathrm{~min}$, the amidolytic activity of $\mathrm{HF}$ was measured as described below.

Ammonium sulfate-precipitable material in PBMC supernates was separated by addition of sufficient solid ammonium sulfate to provide $60 \%$ saturation. The mixture was incubated at $4^{\circ} \mathrm{C}$ overnight and the precipitate that formed, separated by centrifugation at $2^{\circ} \mathrm{C}$ for $15 \mathrm{~min}$ at $2,000 \mathrm{~g}$, was dissolved in sufficient DPBS to restore the original volume and dialyzed for $1 \mathrm{~h}$ against running tap water and overnight against $\sim 100$ vol of DPBS.

DFP-treated PBMC supernatant fluids were prepared by adding $1 / 100$ th vol $0.1 \mathrm{M}$ DFP in isopropanol (final concentration $1 \mathrm{mM}$ ). The mixture was incubated for $90 \mathrm{~min}$ and then dialyzed against 100 vol DPBS at $4^{\circ} \mathrm{C}$ overnight. As a control, the supernates were treated in the same way with $1 / 100$ th vol of isopropanol.

Cycloheximide-treated PBMC were prepared by suspending PBMC in RPMI at a concentration of $5 \times 10^{6}$ cells $/ \mathrm{ml}$. To one of two $12-\mathrm{ml}$ aliquots, $0.12 \mathrm{ml}$ cycloheximide ( $5 \mathrm{mg} / \mathrm{ml}$ DPBS ) was added to provide a concentration of $50 \mu \mathrm{g} / \mathrm{ml}(18 \mu \mathrm{M})$. The two aliquots were incubated with mild agitation for $16 \mathrm{~h}$ at $37^{\circ} \mathrm{C}$ and the cells tested for viability. The aliquots were centrifuged for $10 \mathrm{~min}$ at $500 \mathrm{~g}$ and washed three times in DPBS. The pelleted cells were diluted in DPBS to 5 $\times 10^{6} / \mathrm{ml}$, recentrifuged, the supernatant fluid saved, and the cells resuspended in DPBS at $5 \times 10^{6} / \mathrm{ml}$.

Sodium azide-treated PBMC were prepared by suspending PBMC in RPMI at $10^{7}$ cells $/ \mathrm{ml}$. 9.0-ml aliquots were diluted with $9.0 \mathrm{ml}$ sodium azide $(10 \mathrm{mg} / \mathrm{ml}$ RPMI) or RPMI alone, incubated with mild agitation for $20 \mathrm{~h}$ at $37^{\circ} \mathrm{C}$, washed as described for cycloheximidetreated cells, and tested for viability.

Crude cytosol and particulate fractions of PBMC were separated from $5 \mathrm{ml}$ washed PBMC in DPBS $\left(5 \times 10^{6} \mathrm{cells} / \mathrm{ml}\right)$, snap-frozen in polypropylene vials in a dry ice-ethanol mixture and thawed at $37^{\circ} \mathrm{C}$, repeating the process twice more. The mixture was centrifuged at $100,000 \mathrm{~g}$ for $1 \mathrm{~h}$ at $2^{\circ} \mathrm{C}$, the supernatant cytosol fraction was separated, and the particulate fraction was resuspended in $5 \mathrm{ml}$ DPBS and recentrifuged. The supernatant solution was withdrawn and the particulate fraction was suspended in $5 \mathrm{ml}$ DPBS.

A monocyte-enriched fraction of PBMC was prepared by a modification of the method of Fischer and Koran (17). PBMC were separated from platelet-depleted normal blood, substituting $10 \mathrm{ml}$ RPMI containing $2 \mathrm{mM} \mathrm{L-glutamine}$ and $10 \%$ human $\mathrm{AB}$ serum for DPBS in the final step. The cells were diluted to $5 \times 10^{6} / \mathrm{ml}$ in the same buffer. Quadruplicate aliquots of $11 \mathrm{ml}$ were plated onto $75 \mathrm{~cm}^{2}$ polystyrene tissue culture flasks (Corning Glassware, Corning, NY) and incubated for $70 \mathrm{~min}$ at $37^{\circ} \mathrm{C}$ in a humidified atmosphere of $5 \%$ carbon dioxide and $95 \%$ air. The flasks were then washed three times with $5.0 \mathrm{ml}$ DPBS to remove nonadherent cells. Adherent cells were harvested by adding $5.0 \mathrm{ml}$ DPBS and scraping the flasks with a rubber policeman, transferring the cell suspension to a $50-\mathrm{ml}$ polypropylene tube. The combined cells suspensions of the replicate tubes were centrifuged at $600 \mathrm{~g}$ for $15 \mathrm{~min}$. The sedimented cells, suspended at $5 \times 10^{6} / \mathrm{ml}$ in DPBS, were recentrifuged, the supernatant fluid was removed and saved, and the cells were resuspended at the same concentration. Crude cytosol and particulate fractions of monocytes were prepared as described for PBMC.

A human monocytoid cell line (U937), derived from a human histiocytic lymphoma, was cultured by the method of Sundstrom and Nilsson (18). The cells were washed and centrifuged for $10 \mathrm{~min}$ at $500 \mathrm{~g}$ in polystyrene tubes, the cells were then suspended successively, twice in DPBS-CaMg, once in an equal mixture of DPBS-CaMg and DPBS, and finally in DPBS, separating the cells each time by centrifugation. The final cell suspension, $>95 \%$ viable, was diluted in DPBS to 5 $\times 10^{6} / \mathrm{ml}$, and recentrifuged and the supernatant fluid saved.

Lymphocytes were prepared in the same manner as the monocyte- 
enriched cell fraction by centrifuging nonadherent PBMC at $500 \mathrm{~g}$ for $10 \mathrm{~min}$. The cells were washed three times in DPBS, diluted to 5 $\times 10^{6} / \mathrm{ml}$ with DPBS and resedimented at $500 \mathrm{~g}$ for $10 \mathrm{~min}$. The supernatant fluid and the sedimented cells, resuspended in DPBS to the same concentration, were saved. Crude cytosol and particulate fractions of lymphocytes were separated as described for PBMC.

$T$ and $B$ lymphocytes were prepared by modifications of the methods of Greaves and Brown (19) and Weiner et al. (20). In brief, a cell fraction enriched in $T$ cells was separated from a preparation of PBMC, substituting RPMI-HS for the final addition of DPBS. The cells were diluted to $10^{7} / \mathrm{ml}$ in RPMI-HS. $6 \mathrm{ml}$ were transferred to each of replicate polystyrene tissue culture flasks and incubated at $37^{\circ} \mathrm{C}$ for $1 \mathrm{~h}$ in a humidified atmosphere of $5 \%$ carbon dioxide and $95 \%$ air. The suspensions of nonadherent cells were removed, each flask was rinsed twice with $2.5 \mathrm{ml}$ prewarmed RPMI-FBS, and the combined suspensions were centrifuged at $500 \mathrm{~g}$ for $10 \mathrm{~min}$. The sedimented cells, suspended in $6.5 \mathrm{ml}$ RPMI-FBS, were filtered through $600 \mathrm{mg}$ acidwashed nylon wool (scrubbed nylon, Fenwal Laboratories, Deerfield, IL) wetted with RPMI-FBS, refiltering the cells through the same column three times. Nonadherent cells were filtered through the column by applying $10 \mathrm{ml}$ RPMI-FBS, prewarmed to $37^{\circ} \mathrm{C}$. The effluents of three such columns were combined, centrifuged at $500 \mathrm{~g}$ for $10 \mathrm{~min}$, the cell pellet was suspended in $6.5 \mathrm{ml}$ DPBS, recentrifuged, and the pellet washed three more times with $20 \mathrm{ml}$ DPBS. The cell suspension, diluted to $5 \times 10^{6}$ cells $/ \mathrm{ml}$, was recentrifuged, the supernatant fluid was saved and the cells were resuspended to $5 \times 10^{6} / \mathrm{ml}$. The proportion of $\mathrm{T}$ cells was identified immunologically by cytofluorography, using mouse monoclonal antibodies to the OKT 11 marker (Ortho Diagnostic Systems, Raritan, NJ) (21).

A fraction of PBMC enriched in B cells was separated by washing the nylon wool column used to separate $T$ cells with $50 \mathrm{ml}$ RPMI-FBS and allowing the column to drain. Adherent B cells were dislodged mechanically, eluted with $5 \mathrm{ml} \mathrm{RPMI}$, and centrifuged at $500 \mathrm{~g}$ for 10 min at $10^{\circ} \mathrm{C}$. The pelleted cells were suspended in $1 \mathrm{ml}$ of RPMI-FBS, and diluted to $3 \times 10^{6}$ cells $/ \mathrm{ml} .1 \mathrm{ml}$ of this crude $B$ cell suspension was mixed with $1 \mathrm{ml}$ of a $1 \%$ suspension of sheep erythrocytes in RPMI, centrifuged at $500 \mathrm{~g}$ for $5 \mathrm{~min}$ at $4^{\circ} \mathrm{C}$, and incubated at $4^{\circ} \mathrm{C}$ overnight. The pelleted cells were resuspended and the contents of five such tubes were layered over Ficoll-Paque at a ratio of $8 \mathrm{ml}$ cell suspension and 3 $\mathrm{ml}$ Ficoll-Paque. The tubes were centrifuged at $500 \mathrm{~g}$ for $30 \mathrm{~min}$, the separated cell layer, enriched with B cells, was washed three times in DPBS, and the cells were diluted to $5 \times 10^{6} / \mathrm{ml}$ and recentrifuged. The supernatant fluid was saved and the cells were resuspended in DPBS. The proportion of B cells was identified by cytofluorography, using goat polyvalent immunoglobulin against surface immunoglobulin (PV antibodies, Kallestad Laboratories, Minneapolis, MN) (21).

Granulocytes were separated from $25 \mathrm{ml}$ heparinized venous blood by a modification of published methods $(13,22)$. The blood was diluted with an equal volume of DPBS-CaMg, layered over $18 \mathrm{ml} \mathrm{Fi-}$ coll-Paque, and centrifuged at $450 \mathrm{~g}$ for $\mathbf{4 0} \mathrm{min}$. The supernatant fluid was removed and the thin leukocyte layer, $\sim 3 \mathrm{ml}$, was transferred to each of two 50-ml sterile polystyrene centrifuge tubes. A volume of 24 $\mathrm{ml}$ of distilled water was added to each tube and, after $20 \mathrm{~s}, 8 \mathrm{ml}$ of 0.67 M (3.6\%) sodium chloride was added rapidly to each tube and the contents mixed. The tubes were centrifuged at $250 \mathrm{~g}$ for $10 \mathrm{~min}$ at $2^{\circ} \mathrm{C}$, the pelleted granulocytes were resuspended in $24 \mathrm{ml}$ water and the process repeated. The cells were then suspended in $10 \mathrm{ml}$ DPBS-CaMg and rewashed, twice with DPBS-CaMg, once with an equal mixture of DPBS and DPBS-CaMg, and finally with DPBS. The pelleted cells were suspended in DPBS at $5 \times 10^{6} / \mathrm{ml}$. The cell suspension and the supernatant fluid after centrifugation were saved.

Erythrocytes were separated from $10 \mathrm{ml}$ citrated venous blood by centrifugation at $250 \mathrm{~g}$ for $15 \mathrm{~min}$. The supernatant, platelet-rich plasma was withdrawn and $4 \mathrm{ml}$ of the pelleted erythrocytes were aspirated from the bottom of the tube, recentrifuged, and the bottom 3 $\mathrm{ml}$ of erythrocytes were withdrawn and washed three times with $3 \mathrm{ml}$ DPBS, sedimenting the cells each time at $2,000 \mathrm{~g}$ for $10 \mathrm{~min}$. The erythrocytes were then diluted to $2 \times 10^{7}$ cells $/ \mathrm{ml}$ with DPBS and was recentrifuged at $2,000 \mathrm{~g}$ for $10 \mathrm{~min}$. The supernatant fluid was removed and saved, and the erythrocytes were rediluted to $2 \times 10^{7}$ cells $/ \mathrm{ml}$. No platelets or leukocytes were seen in smeared preparations stained with Wright-Giemsa stain.

Platelets were separated from $40 \mathrm{ml}$ citrated blood by a modification of Kinlough-Rathbone's (23) method. The platelet-rich plasma, sedimented at $200 \mathrm{~g}$ for $10 \mathrm{~min}$, was recentrifuged at the same speed to reduce contamination with erythrocytes. The platelet-rich plasma was mixed with an equal volume of DPBS-Alb, incubated at $37^{\circ} \mathrm{C}$ for 15 $\mathrm{min}$ and centrifuged at $1,800 \mathrm{~g}$ for $10 \mathrm{~min}$. The pelleted platelets were washed twice more in $10 \mathrm{ml}$ of DPBS-Alb and suspended in DPBS (without albumin) at $10^{8}$ cells $/ \mathrm{ml}$. This suspension and the supernatant fluid after recentrifugation were saved. No erythrocytes or leukocytes were seen in smears of the platelet suspension stained with WrightGiemsa stain.

The effect of cell suspensions or the supernatant fluid of cells suspensions on activation of HF by ellagic acid was measured by incubating $0.1 \mathrm{ml} \mathrm{HF}(0.05 \mathrm{U} / \mathrm{ml}$ in BS-Alb) with $0.1 \mathrm{ml}$ of the agent to be tested, diluted serially with DPBS, for $10 \mathrm{~min}$ at $37^{\circ} \mathrm{C}$ in $12 \times 75 \mathrm{~mm}$ polystyrene tubes. Thereafter, $0.05 \mathrm{ml}$ ellagic acid $\left(2 \times 10^{-5} \mathrm{M}\right.$ in BS) was added to each tube. Incubation was continued for $60 \mathrm{~min}$, after which $1.0 \mathrm{ml}$ HPPAN was added. Incubation was continued for 60 min and the reaction was then stopped by addition of $0.3 \mathrm{ml}$ glacial acetic acid. The amount of $p$-nitroaniline ( $p$-NA) released from HPPAN was measured spectrophotometrically at $405 \mathrm{~nm}$ against blanks in which glacial acetic acid was added before substrate, in comparison to the OD of $p$-NA solutions. Mixtures containing cells were centrifuged at $800 \mathrm{~g}$ for $10 \mathrm{~min}$ before measurement of OD. Controls included the substitution of appropriate buffers for the test solution, HF, or ellagic acid. The degree of inhibition by the test solutions was determined in comparison to the amidolytic activity of a range of concentrations of HF. The coefficient of variation of the amidolytic assay of $\mathrm{HF}$ was $3.2 \%(\mathrm{SD} \pm 3.1 \%, \mathrm{SE} \pm 1.0 \%)$ of any given value excluding observations in which the OD was 0.010 or less. The coefficient of variation of the assay for inhibitory activity was $3.7 \%$ (SD $\pm 3.4 \%$, $\mathrm{SE} \pm 0.6 \%$ ). Variations of this technique are described in the text. All experiments were performed in replicate.

To test the effect of LBTI and SBTI on PBMC supernates, $0.1 \mathrm{ml}$ of supernate was incubated with $0.05 \mathrm{ml}$ LBTI or SBTI in BS, serially diluted with BS, for $10 \mathrm{~min}$ at $37^{\circ} \mathrm{C}, 0.05 \mathrm{ml} \mathrm{HF}(0.1 \mathrm{U} / \mathrm{ml} \mathrm{BS}-\mathrm{Alb})$ was added and incubation was continued for $10 \mathrm{~min}$, after which 0.05 $\mathrm{ml} 2 \times 10^{-5} \mathrm{M}$ ellagic acid was added. After an additional $60 \mathrm{~min}, 1.0$ $\mathrm{ml}$ HPPAN and $0.05 \mathrm{ml}$ BS were added, and the assay continued as described above. As controls, BS was substituted for LBTI or SBTI in the initial mixture, and LBTI or SBTI was substituted for BS in the final mixture.

The effect of the supernatant fluid of cell suspensions on the activation of $\mathrm{HF}$ by glass was measured by mixing $0.25 \mathrm{ml} \mathrm{HF}(0.05 \mathrm{U} / \mathrm{ml}$ BS-Alb) or bovine albumin alone and $0.25 \mathrm{ml}$ supernatant fluid, diluted serially with DPBS, or DPBS alone. Aliquots of $0.2 \mathrm{ml}$ were transferred to $10 \times 75 \mathrm{~mm}$ disposable borosilicate glass tubes (Fisher Scientific Co., Pittsburgh, PA). The tubes were incubated for $60 \mathrm{~min}$ at $37^{\circ} \mathrm{C}$, agitating the tubes continuously in a mechanical shaker. Thereafter $0.1 \mathrm{ml}$ DPBS and $1.0 \mathrm{ml}$ HPPAN were added and incubation and shaking were continued for $60 \mathrm{~min}$, after which $0.3 \mathrm{ml}$ glacial acetic acid was added. The amount of $p$-NA released was measured as described above.

The capacity of PBMC supernates to inhibit the clot-promoting properties of glass was tested by an earlier method (24). In duplicate, 10 $\times 75 \mathrm{~mm}$ disposable glass tubes were coated with $0.2 \mathrm{ml}$ samples of supernate or BS. Volumes of $0.1 \mathrm{ml}$ each of normal pooled plasma and Centrolex $P$ were incubated in these tubes at $37^{\circ} \mathrm{C}$ for $1 \mathrm{~min}$, and the clotting time was measured at this temperature after addition of $0.1 \mathrm{ml}$ $0.025 \mathrm{M}$ calcium chloride, prewarmed at $37^{\circ} \mathrm{C}$.

To determine whether binding took place between $\mathrm{HF}$ and the inhibitory agent(s) in PBMC supernates, a concentrate of PBMC supernate was bound covalently to cyanogen bromide-activated agarose (CNBr-activated Sepharose 4B, Pharmacia Fine Chemicals) according 
to the manufacturer's directions, at a ratio of $10 \mathrm{mg}$ protein to $1 \mathrm{~g}$ gel. A control gel was prepared in the same way, omitting addition of PBMC supernate and blocking the active site with ethanolamine. A volume of $2 \mathrm{ml}$ of gel was packed in polypropylene Econo-columns (i.d. $0.8 \mathrm{~cm}$; Bio-Rad Laboratories) and washed with DPBS before use. $1 \mathrm{ml} \mathrm{HF}(1.0 \mathrm{U} / \mathrm{ml} \mathrm{BS}-\mathrm{Alb}, 48 \mathrm{U} / \mathrm{mg}$ protein) was filtered through each column, eluting with DPBS. 1-ml aliquots were collected in polystyrene tubes and assayed for coagulant HF activity in comparison with that of pooled normal plasma (25).

The effect of PBMC supernates on the coagulant action of thrombin was tested in $10 \times 75 \mathrm{~mm}$ polystyrene tubes by measuring the clotting time at $37^{\circ} \mathrm{C}$ of a mixture of $0.1 \mathrm{ml}$ each of pooled normal human plasma, a concentrate of supernate in DPBS, and bovine thrombin $(5 \mathrm{U} / \mathrm{ml})$. The presence of fibrinogen in supernates was examined in the same way, omitting plasma. The effect of PBMC supernates on the prothrombin time and kaolin-activated partial thromboplastin time was similarly measured (25).

The effect of PBMC supernates on the amidolytic properties of activated PTA (26) and plasmin (25) and the esterolytic properties of Cī (27) was determined by published methods. The effect of PBMC supernates on the amidolytic properties of activated Stuart factor was measured by an adaptation of method I of Ødegard et al. (28), incubating $0.2 \mathrm{ml}$ concentrated PBMC supernate $(1.5 \mathrm{mg}$ protein $/ \mathrm{ml}$ DPBS) or DPBS alone at $37^{\circ} \mathrm{C}$ for 5 min with $0.1 \mathrm{ml}$ activated Stuart factor $(2 \mathrm{U} / \mathrm{ml} 0.25 \%$ bovine albumin in $\mathrm{BS}$, specific activity 1,200 $\mathrm{U} / \mathrm{ml}$ protein), in $12 \times 75 \mathrm{~mm}$ polystyrene tubes. Thereafter, $0.2 \mathrm{ml}$ $10^{-3} \mathrm{M} \mathrm{S} 2222$ was added, incubation was continued for $7 \mathrm{~min}$, and the reaction was stopped by addition of $0.3 \mathrm{ml}$ glacial acetic acid. The amount of $p$-NA released was measured at $405 \mathrm{~nm}$ in comparison to blanks to which acetic acid was added before substrate.

Cell counting was carried out with a Coulter counter (model ZM, Coulter Electronics, Hialeah, FL). The proportion of monocytes and lymphocytes in suspensions of PBMC was estimated by histochemical staining of monocytes for nonspecific esterase (17). Differential counts of granulocytes were performed by Wright-Giemsa staining of smeared cells. T cells and B cells were identified with an automated flow-cytometry system (Coulter Epics V, Coulter Electronics) (21). Cell viability was tested by trypan blue exclusion (29).

Protein assays were performed by the method of Lowry (30).

All centrifugations were at room temperature unless otherwise stated, at low speeds in a refrigerated centrifuge (model PR-2, Damon/International Centrifuge Co.,) at $2^{\circ} \mathrm{C}$ and at room temperature in a centrifuge (model UV, Damon/International Centrifuge Co.). Ultracentrifugation was performed in a centrifuge (model L5-65; Beckman Instruments, Inc., Fullerton, CA) at $2^{\circ} \mathrm{C}$.

Dialyses were performed in Spectro-Por 2 cellulose casings (6.4 mm diam molecular weight cut-off 12-14,000; Spectrum Medical Industries, Los Angeles, CA).

\section{Results}

The inhibitory effect of PBMC suspensions and their supernatant fluids on the activation of HF by ellagic acid. Suspensions of PBMC inhibited the activation of HF by ellagic acid, as measured by amidolysis of HPPAN. In a typical experiment, PBMC, at initial concentrations of $6.25 \times 10^{5}$ cells $/ \mathrm{ml}$ or more, significantly inhibited activation of HF (Table I). Similarly, the supernatant fluid of PBMC cell suspensions inhibited activation of HF. Inhibitory properties for the activation of HF were detected in variable but essentially similar amounts in the supernatant fluids of nine further washes of the PBMC suspension (data not shown). The inhibitory activity of different supernatant fluid preparations was roughly proportional to their protein content; a dilution of supernate that inhibited half the amidolytic activity of the HF in a mixture of HF and supernate had a protein content averaging $7.3 \mu \mathrm{g} / \mathrm{ml}(\mathrm{SD} \pm 2.72 \mu \mathrm{g} / \mathrm{ml})$.
The inhibitory properties of platelets, monocytes and lymphocytes on the activation of HF by ellagic acid. The PBMC used in the experiments described thus far were contaminated with platelets, containing, on the average, $13.3(\mathrm{SD} \pm 7.0)$ platelets per PBMC (Table I). Platelet suspensions and their supernates inhibited activation of HF by ellagic acid, but this was significant only at relatively high concentrations of platelets (Table II).

Comparison of the data presented in Tables I and II suggests that a portion of the inhibitory effect of PBMC suspensions was due to their content of platelets. When PBMC were prepared from normal human blood that had been depleted of $\sim 95 \%$ of its platelet content, inhibition of the activation of HF by PBMC was reduced by $\sim 50 \%$, and by the supernates of PBMC suspensions by $\sim 75 \%$. Thus, a significant portion of the inhibitory properties of PBMC suspensions could be attributed to platelets. That platelets were not solely responsible for the inhibitory properties of PBMC suspensions was demonstrated in studies of PBMC prepared from the blood of a patient with severe thrombocytopenia. At concentrations of platelets that were not inhibitory (Table II), both the cell suspension and the supernatant fluid inhibited activation of HF (Table I).

The PBMC were mixtures of $\sim 80 \%$ lymphocytes and $20 \%$ monocytes. A monocyte-enriched fraction of PBMC, prepared from platelet-depleted blood, and the supernate of this fraction inhibited activation of HF (Table III). Similarly, the supernatant fluid of a suspension of cultured monocytoid cells (U937) inhibited activation of HF (Table III).

A lymphocyte-enriched fraction of PBMC, prepared from blood that had been depleted of platelets, and the supernate of this fraction inhibited the activation of HF (Table III). Both T and $B$ lymphocytes and their supernates were inhibitory (Tables III and III).

The inhibitory properties of granulocytes and erythrocytes and their supernatant fluids on the activation of HF by ellagic acid. Granulocytes, separated as described, and the supernatant fluid of granulocyte suspensions inhibited activation of HF to approximately the same degree as PBMC suspensions (Table IV).

Neither erythrocytes nor the supernatant fluid of erythrocyte suspensions had significant inhibitory properties $(\mathrm{Ta}-$ ble IV).

Some properties of the inhibitory activity of PBMC supernates. The inhibitory properties of PBMC suspensions and their supernates were directed against the activation of $\mathrm{HF}$ and not at the amidolytic properties of activated HF. Addition of cells or supernatant fluid after HF had been incubated with ellagic acid for $60 \mathrm{~min}$ was without effect; the cells and supernatant fluid themselves did not have amidolytic properties for this substrate (Table I).

After ultracentrifugation, both the cytosol and particulate fractions of PBMC inhibited the activation of HF by ellagic acid, but in repeated experiments the cytosol appeared to be relatively more inhibitory (Table V). Similarly, both cytosol and particulate fractions of lymphocytes and monocytes were inhibitory (data not shown).

The inhibitory properties of PBMC supernates were not reduced by filtration of supernates through a Millex-GV filter, said to retain particles $>0.22 \mu \mathrm{m}$ diam), nor by dialysis through casings with a mol wt cut-off of $12-14,000$.

The inhibitory properties of PBMC supernates were re- 
Table I. Effect of Peripheral Blood Mononuclear Cells on the Activation of HF by Ellagic Acid

\begin{tabular}{|c|c|c|c|c|c|}
\hline \multicolumn{3}{|l|}{ Test mixture } & \multicolumn{3}{|l|}{ Amidolysis* } \\
\hline \multicolumn{2}{|l|}{ Cell suspension } & \multirow[t]{2}{*}{ Supernate dilution } & & & \\
\hline PBMC & Platelets & & Cell suspension & Supernate & Buffer \\
\hline cells $/ m l$ & cells $/ m l$ & & & released $/ \mathrm{ml} / \mathrm{h}$ & \\
\hline \multicolumn{6}{|c|}{ A. Normal blood } \\
\hline $5 \times 10^{6}$ & $9 \times 10^{7}$ & Undilute & 2.8 & 0.5 & - \\
\hline $2.5 \times 10^{6}$ & $4.5 \times 10^{7}$ & $1 / 2$ & 3.4 & 7.5 & - \\
\hline $1.25 \times 10^{6}$ & $2.25 \times 10^{7}$ & $1 / 4$ & 6.9 & 18.2 & - \\
\hline $6.25 \times 10^{5}$ & $1.25 \times 10^{7}$ & $1 / 8$ & 16.8 & 24.5 & - \\
\hline $3.13 \times 10^{5}$ & $6.25 \times 10^{6}$ & $1 / 16$ & 24.1 & 25.4 & - \\
\hline 0.0 & 0.0 & $\infty$ & - & - & 27.6 \\
\hline $5 \times 10^{6 \ddagger}$ & $9 \times 10^{7 \neq}$ & Undilute $^{\ddagger}$ & 1.9 & 0.8 & - \\
\hline $5 \times 10^{68}$ & $9 \times 10^{78}$ & Undilute $^{\S}$ & 28.5 & 25.4 & - \\
\hline \multicolumn{6}{|c|}{ B. Blood of a patient with aplastic anemia } \\
\hline $5 \times 10^{6}$ & $2.7 \times 10^{6}$ & Undilute & 3.4 & 0.7 & - \\
\hline $2.5 \times 10^{6}$ & $1.35 \times 10^{6}$ & $1 / 2$ & 3.7 & 1.6 & - \\
\hline $1.25 \times 10^{6}$ & $6.75 \times 10^{5}$ & $1 / 4$ & 12.3 & 12.0 & - \\
\hline $6.25 \times 10^{5}$ & $3.38 \times 10^{5}$ & $1 / 8$ & 15.9 & 18.7 & - \\
\hline $3.13 \times 10^{5}$ & $1.69 \times 10^{5}$ & $1 / 16$ & 17.6 & 19.4 & - \\
\hline 0.0 & 0.0 & $\infty$ & - & - & 21.4 \\
\hline
\end{tabular}

\begin{abstract}
* Amidolytic activity generated in a mixture of HF, test mixture (serially diluted with DPBS) and ellagic acid (see Methods). The test mixtures were PBMC $\left(5 \times 10^{6}\right.$ cells/ml DPBS), the supernatant of the PBMC suspension and DPBS alone (buffer). $(A)$ The PBMC contained $9 \%$ monocytes and $91 \%$ lymphocytes, the platelet count in the undiluted PBMC suspension was $9 \times 10^{7} \mathrm{cells} / \mathrm{ml}$ or 18 platelets per PBMC, and the protein content of the supernate was $38 \mu \mathrm{g} / \mathrm{ml}$. (B) PBMC were prepared from the blood of a patient with aplastic anemia (peripheral blood plate-

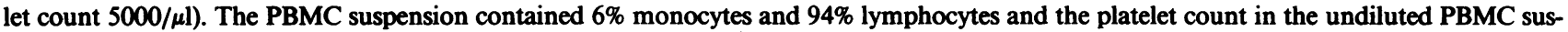
pension was $2.7 \times 10^{6} \mathrm{cells} / \mathrm{ml}$ or approximately one platelet for each $2 \mathrm{PBMC}$. The protein content of the undiluted supernate was $16 \mu \mathrm{g} / \mathrm{ml}$. In $12 \times 75-\mathrm{mm}$ polystyrene tubes, $0.1 \mathrm{ml} \mathrm{HF}(0.05 \mathrm{U} / \mathrm{ml}, 58 \mathrm{U} / \mathrm{mg}$ protein $)$ and $0.1-\mathrm{ml}$ test mixture were incubated at $37^{\circ} \mathrm{C}$ for $10 \mathrm{~min}$, after which $0.05 \mathrm{ml} 4 \times 10^{-5} \mathrm{M}$ ellagic acid was added and incubation was continued for $60 \mathrm{~min}$. Thereafter, $0.1 \mathrm{ml}$ DPBS and $1.0 \mathrm{ml} \mathrm{HPPAN}$ were added, incubation was continued for an additional $60 \mathrm{~min}$, and the reaction was stopped by addition of $0.3 \mathrm{ml}$ glacial acetic acid. The amount of $p$-nitroaniline ( $p$-NA) that had been released was measured against suitable blanks to which glacial acetic acid had been added before HPPAN. ${ }^{\ddagger}$ Bovine albumin in BS substituted for HF in the original mixture. ${ }^{8}$ DPBS substituted for PBMC or PBMC supernate in the original mixture and $0.1 \mathrm{ml}$ PBMC or PBMC supernate added to the mixture instead of DPBS after the 60-min incubation of the mixture of HF and ellagic acid.
\end{abstract}

Table II. Effect of Platelets on the Activation of HF by Ellagic Acid

\begin{tabular}{llllll}
\hline \multirow{2}{*}{ Test mixture } & \multicolumn{3}{l}{ Amidolysis* } \\
\cline { 1 - 3 } Platelets & $\begin{array}{l}\text { Supernate } \\
\text { dilution }\end{array}$ & & Platelets & Supernate & Buffer \\
\hline cells $/ m l$ & & & nmol $p$-NA released $/ m l / h$ & \\
$10^{8}$ & & & & 3.4 & - \\
$5 \times 10^{7}$ & $1 / 2$ & & 19.0 & 9.8 & - \\
$2.5 \times 10^{7}$ & $1 / 4$ & & 20.9 & 18.0 & - \\
$1.25 \times 10^{7}$ & $1 / 8$ & & 23.6 & 22.0 & - \\
$6.25 \times 10^{6}$ & $1 / 16$ & & 24.6 & 25.2 & - \\
0.0 & $\infty$ & - & - & 24.6
\end{tabular}

* Amidolytic activity generated in a mixture of HF, test mixture, and ellagic acid (see Methods). The test mixtures were suspensions of platelets $\left(10^{8} \mathrm{cells} / \mathrm{ml}\right)$, serially diluted with DPBS, the supernatant fluid separated from each suspension of platelets and DPBS alone. The assays were performed as described in the footnote to Table $I$. The specific activity of the HF was $58 \mathrm{U} / \mathrm{mg}$ protein. tained after incubation at room temperature or $37^{\circ} \mathrm{C}$ overnight but were reduced by incubation at higher temperatures for $30 \mathrm{~min}$ by approximately one-fourth at $56^{\circ} \mathrm{C}$ and one-half at $60^{\circ} \mathrm{C}$, and essentially completely by incubation in a boiling water bath for this time.

Binding of HF to the inhibitory agent(s) in PBMC supernates could not be demonstrated. The coagulant titer of HF was the same, whether filtered through a column of agarose to which PBMC supernate had been covalently linked, or through a control column of agarose.

Incubation of PBMC or PBMC supernates with trypsin reduced their inhibitory properties, suggesting that a protein component participated in inhibition of the activation of $\mathrm{HF}$ (Table VI). In agreement with this interpretation, approximately half of the inhibitory properties of PBMC supernates were precipitated by ammonium sulfate at $60 \%$ saturation.

No evidence was obtained that the inhibitory properties of PBMC supernatant fluids were enzymatic. The inhibitory properties of PBMC supernate appeared to be essentially instantaneous (Fig. 1). When PBMC supernate was incubated 
Table III. Effect of Monocytes and Lymphocytes on the Activation of $\mathrm{HF}$ by Ellagic Acid

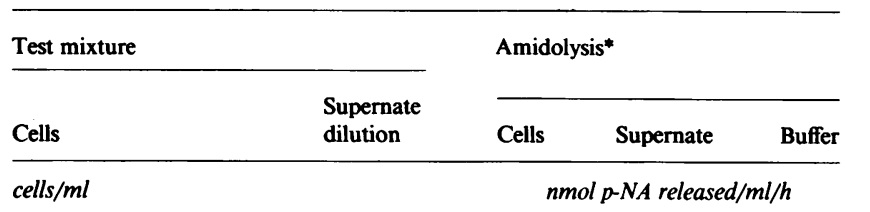

A. Adherent cells

$5 \times 10^{6}$
$2.5 \times 10^{6}$
$1.25 \times 10^{6}$
$6.25 \times 10^{5}$
0.0

Undilute
$1 / 2$
$1 / 4$
$1 / 8$
$\infty$

$\begin{array}{rr}0.6 & 0.3 \\ 0.1 & 0.0 \\ 0.6 & 6.4 \\ 13.5 & 21.8 \\ - & -\end{array}$

-
-
-
32.1

B. Monocytoid cells

-
-
-
-

C. Nonadherent cells

$5 \times 10^{6}$
$2.5 \times 10^{6}$
$1.25 \times 10^{6}$
$6.25 \times 10^{5}$
0.0

Undilute
$1 / 2$
$1 / 4$
$1 / 8$
$\infty$

$\begin{array}{rr}0.0 & 0.0 \\ 1.0 & 2.6 \\ 10.3 & 19.6 \\ 19.3 & 25.6 \\ - & -\end{array}$

D. B cells

$$
\begin{array}{r}
5 \times 10^{6} \\
2.5 \times 10^{6} \\
1.25 \times 10^{6} \\
6.25 \times 10^{5} \\
0.0
\end{array}
$$

Undilute
$1 / 2$
$1 / 4$
$1 / 8$
$\infty$

$\begin{array}{lr}- & 1.5 \\ - & 3.8 \\ - & 11.5 \\ - & 20.9 \\ - & -\end{array}$

-
-
-
22.9

E. T cells

$\begin{array}{rlrrr}5 \times 10^{6} & \text { Undilute } & 0.0 & 1.3 & - \\ 2.5 \times 10^{6} & 1 / 2 & 0.7 & 11.8 & - \\ 1.25 \times 10^{6} & 1 / 4 & 1.6 & 18.2 & - \\ 6.25 \times 10^{5} & 1 / 8 & 8.0 & 21.3 & - \\ 0.0 & \infty & - & - & 22.0\end{array}$

* Amidolytic activity generated in a mixture of HF, test mixture (serially diluted with DPBS) and ellagic acid (see Methods). The test mixtures in $A$ were polystyrene-adherent cells, at an initial concentration of $5 \times 10^{6}$ cells $/ \mathrm{ml}$, prepared from PBMC that had been separated from platelet-depleted blood, and the supernate of the initial adherent cell suspension; the adherent cell suspension contained $94 \%$ monocytes, $6 \%$ lymphocytes and $2.3 \times 10^{7}$ platelets $/ \mathrm{ml}$ or 4.6 platelets per adherent cell. The test mixture in $B$ was the supernate of a suspension of human monocytoid cells (U-937) containing $5 \times 10^{6}$ cells $/ \mathrm{ml}$. The text mixtures in $C$ were nonadherent cells, at an initial concentration of $5 \times 10^{6}$ cells $/ \mathrm{ml}$, prepared from PBMC that had been separated from platelet-depleted blood, and the supernate of the initial nonadherent cell suspension; the nonadherent cell suspension contained 1.5 percent monocytes, 98.5 percent lymphocytes, and 2.4 $\times 10^{6}$ platelets $/ \mathrm{ml}$, or one platelet per 2 nonadherent cells. The test mixtures in $D$ and $E$ were $B$ and $T$ cells and their supernates, respectively. The B cell preparation contained 85 per cent $B$ cells, and the $T$ cell preparation, 81 percent $T$ cells. The assay was performed as described in the footnote to Table I. The specific activity of the HF used in $A, C, D$, and $E$ was $58 \mathrm{U} / \mathrm{mg}$ protein, and in $B, 98 \mathrm{U} / \mathrm{mg}$ protein. $A, B, C, D$, and $E$ represent separate experiments.
Table IV. Effect of Granulocytes and Erythrocytes on the Activation of $\mathrm{HF}$ by Ellagic Acid

\begin{tabular}{llllll}
\hline \multirow{2}{*}{ Test mixture } & \multicolumn{3}{l}{ Amidolysis* } \\
\cline { 1 - 3 } Cells & $\begin{array}{l}\text { Supernate } \\
\text { dilution }\end{array}$ & & Cells & Supernate & Buffer \\
\hline cells/ml & & & nmol p-NA released/ml/h \\
A. Granulocytes & & & & \\
$5 \times 10^{6}$ & Undilute & & & 3.3 & - \\
$2.5 \times 10^{6}$ & $1 / 2$ & & 0 & 8.9 & - \\
$1.25 \times 10^{6}$ & $1 / 4$ & & 3.5 & 15.9 & - \\
$6.25 \times 10^{5}$ & $1 / 8$ & & 4.2 & 18.2 & - \\
$3.12 \times 10^{5}$ & $1 / 16$ & & 11.8 & 20.1 & - \\
$1.56 \times 10^{5}$ & $1 / 32$ & & 15.8 & 20.3 & - \\
0.0 & $\infty$ & & - & - & 20.7 \\
B. Erythrocytes & & & & \\
$2 \times 10^{7}$ & Undilute & 19.9 & 20.7 & - \\
0.0 & $\infty$ & - & - & 21.5 \\
\hline
\end{tabular}

* Amidolytic activity generated in $12 \times 75 \mathrm{~mm}$ polystyrene tubes in a mixture of $0.1 \mathrm{ml} \mathrm{HF}(0.05 \mathrm{U} / \mathrm{ml}, 58 \mathrm{U} / \mathrm{mg}$ protein $), 0.1 \mathrm{ml}$ test mixture, serially diluted with DPBS, and $0.05 \mathrm{ml} 2 \times 10^{-5} \mathrm{M}$ ellagic acid (see Methods). The test mixtures included neutrophils $\left(5 \times 10^{6}\right.$ cells/ml DPBS), erythrocytes $\left(2 \times 10^{7}\right.$ cells/ml DPBS), and the supernates of these cell suspensions. The granulocyte preparation contained $94 \%$ segmented neutrophils, $4 \%$ eosinophils and $2 \%$ lymphocytes. No platelets were discerned in stained smears of the granulocyte or erythrocyte suspensions. The protein content of the undiluted (100\%) supernatant of the granulocyte suspension was $17 \mu \mathrm{g} / \mathrm{ml}$, and of the erythrocyte suspension, $<8 \mu \mathrm{g} / \mathrm{ml}$.

with $\mathrm{HF}$ for varying intervals before addition of ellagic acid, its

\begin{tabular}{|c|c|c|c|c|}
\hline \multirow[b]{2}{*}{$\begin{array}{l}\text { Test mixture } \\
\text { dilution }\end{array}$} & \multicolumn{4}{|c|}{ Amidolysis* } \\
\hline & Cells & Cytosol & $\begin{array}{l}\text { Particulate } \\
\text { fraction }\end{array}$ & Buffer \\
\hline & \multicolumn{4}{|c|}{$n m o l p-N A$ released $/ m l / h$} \\
\hline Undilute & 3.7 & 1.8 & 4.8 & - \\
\hline $1 / 2$ & 2.2 & 0.6 & 4.6 & - \\
\hline $1 / 4$ & 1.9 & 1.9 & 21.0 & - \\
\hline $1 / 8$ & 5.9 & 1.3 & 21.9 & - \\
\hline $1 / 16$ & 15.6 & 13.5 & 20.2 & - \\
\hline $1 / 32$ & 18.0 & 17.7 & 19.8 & - \\
\hline$\infty$ & - & - & - & 20.4 \\
\hline
\end{tabular}
inhibitory activity gradually decreased. In contrast, when supernate was incubated with ellagic acid for a variable period

Table V. Effect of Cytosol and Particulate Fractions of PBMC on the Activation of HF by Ellagic Acid

* Amidolytic activity generated in $12 \times 75 \mathrm{~mm}$ polystyrene tubes in a mixture of HF, test mixture (serially diluted with DPBS). The test mixtures were PBMC $\left(5 \times 10^{6}\right.$ cells/ml DPBS), the cytosol fraction of PBMC separated by ultracentrifugation of freeze-thawed PBMC, the particulate fraction after ultracentrifugation, diluted with PBMC to the original volume, and DPBS alone (buffer). The PBMC contained $20 \%$ monocytes and $80 \%$ lymphocytes. Amidolytic activity was measured as noted in the footnote to Table I. The specific activity of the HF was $100 \mathrm{U} / \mathrm{mg}$ protein. 
Table VI. Effect of Trypsin on the Inhibitory Properties of PBMC and PBMC Supernate

\begin{tabular}{llll}
\hline Test mixture & Trypsin & HF & Amidolysis* \\
\hline & & & nmol p-NA released/ml/h \\
DPBS & 0 & + & 15.8 \\
DPBS & + & + & 17.8 \\
DPBS & + & 0 & 0 \\
PBMC & 0 & + & 4.6 \\
PBMC & + & + & 11.0 \\
Supernate & 0 & + & 5.1 \\
Supernate & + & + & 14.1 \\
& & & \\
\hline
\end{tabular}

* In $12 \times 75 \mathrm{~mm}$ polystyrene tubes, $0.1 \mathrm{ml}$ DPBS or PBMC or PBMC supernate was incubated with $0.025 \mathrm{ml}$ bovine trypsin $(0.05$ $\mathrm{mg} / \mathrm{ml}$ ) or BS at $37^{\circ} \mathrm{C}$ for $2 \mathrm{~h}$. Thereafter, $0.025 \mathrm{ml} \mathrm{LBTI}, 0.2 \mathrm{mg} / \mathrm{ml}$ and $0.05 \mathrm{ml} \mathrm{HF}(0.1 \mathrm{U} / \mathrm{ml})$ or BS-Alb alone were added in rapid succession and, after $10 \mathrm{~min}, 0.05 \mathrm{ml}$ ellagic acid, followed, after $1 \mathrm{~h}$, by $1 \mathrm{ml}$ HPPAN. After an additional $60 \mathrm{~min}$, the reaction was stopped by addition of $0.3 \mathrm{ml}$ glacial acetic acid and the amount of $p$-nitroaniline (p-NA) released was measured against blanks to which glacial acetic acid was added before addition of substrate. The PBMC were suspended at a concentration of $5 \times 10^{6} / \mathrm{ml} \mathrm{DPBS}$; the supernate of PBMC was in the same buffer. Trypsin, LBTI, and ellagic acid were dissolved in BS. The specific activity of the $\mathrm{HF}$ was $100 \mathrm{U} / \mathrm{mg}$ protein.

before addition of $\mathrm{HF}$, it retained its inhibitory properties for at least $60 \mathrm{~min}$. At the concentrations tested, the inhibitory properties of PBMC supernatant fluids were not impaired by incubation with $1 \mathrm{mM}$ DFP. Nor was inhibition of the activation of HF prevented by addition of $0.5 \mathrm{mM}$ EDTA or $0.5 \mathrm{mM}$ benzamidine to the initial mixture of HF and supernate. Appropriate concentrations of SBTI or LBTI are known to inhibit the amidolytic properties of ellagic acid-activated HF (31). At concentrations of $30 \mu \mathrm{g} / \mathrm{ml}$ or less in the mixture of PBMC supernate, HF and ellagic acid, concentrations of SBTI or LBTI that did not affect amidolysis by activated HF, these agents did not block the inhibitory properties of PBMC supernates.

The inhibitory properties of PBMC supernates could not be identified with other agents that might influence the activa-

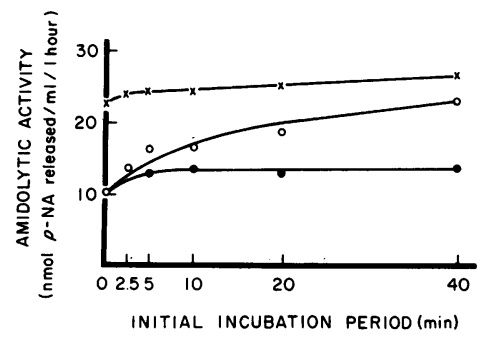

Figure 1. Time course of inhibition by PBMC supernates of the activation of HF by ellagic acid. In 12 $\times 75 \mathrm{~mm}$ polystyrene tubes, $0.1 \mathrm{ml}$ PBMC supernate (diluted $50 \%$ with DPBS) was incubated for $10 \mathrm{~s}$ to 40 min with 0.05 $\mathrm{ml}$ ellagic acid $\left(2 \times 10^{-5}\right.$

$\mathrm{M})$, after which $0.1 \mathrm{ml} \mathrm{HF}(0.05 \mathrm{U} / \mathrm{ml}, 58 \mathrm{U} / \mathrm{mg}$ protein $)$ was added. The mixture was incubated for an additional $60 \mathrm{~min}, 1.0 \mathrm{ml}$ HPPAN was added, and incubation was continued for $60 \mathrm{~min}(\bullet)$. Conversely, $0.1 \mathrm{ml}$ supernate was incubated with $0.1 \mathrm{ml} \mathrm{HF}$ for $10 \mathrm{~s}$ to $40 \mathrm{~min}$, after which $0.5 \mathrm{ml}$ ellagic acid was added and the procedure continued as before (o). The reaction was stopped by addition of 0.3 $\mathrm{ml}$ glacial acetic acid and the amount of $p$-NA released was measured (see Methods). The amidolytic activity generated in mixtures of $0.1 \mathrm{ml} \mathrm{HF}$ and $0.1 \mathrm{ml} \mathrm{DPBS}$, incubated for $10 \mathrm{~s}$ to $40 \mathrm{~min}$ before addition of ellagic acid, was also measured $(x)$. tion of HF. Thus, the thrombin time was unaltered in a mixture of $0.2 \mathrm{ml}$ each of normal plasma, concentrated PBMC supernate $(56 \mu \mathrm{g}$ protein $/ \mathrm{ml})$ and bovine thrombin $(5 \mathrm{U} / \mathrm{ml})$, suggesting that the inhibitory effects of PBMC supernates were not attributable to heparinlike agents.

Supporting this interpretation, no uronic acid was detected in a concentrate of PBMC supernate containing $1 \mathrm{mg}$ protein/ $\mathrm{ml}$. Moreover, the addition of PF4, at concentrations as high as $75 \mu \mathrm{g} / \mathrm{ml}$ in a mixture of PBMC supernate and HF did not neutralize the inhibitory properties of the supernate. Rather, as demonstrated in experiments in which its concentration was reduced to $0.24 \mu \mathrm{g} / \mathrm{ml}$, PF4 itself inhibited the activation of $\mathrm{HF}$ by ellagic acid, and its inhibitory activity was additive to that of PBMC supernates.

The inhibitory properties of PBMC supernates could not be attributed to PF4, which could not be demonstrated upon immunodiffusion against antiserum against PF4; a crude IgG fraction of this antiserum did not neutralize the inhibitory properties of PBMC supernates (Table VII).

PBMC supernates did not contain material coagulable with thrombin. They did not alter the prothrombin time or activated partial thromboplastin time of normal plasma (data not shown). Nor did they inhibit the amidolytic properties of $C \overline{1}$ (data not shown); Cī inhibitor was not demonstrable by immunodiffusion, and a crude immunoglobulin fraction of specific antiserum did not reduce the inhibitory properties of PBMC supernates (Table VII).

Table VII. Effect of Antiserums on the Inhibitory Properties of PBMC Supernate

\begin{tabular}{ll}
\hline & Amidolysis* \\
\hline & nmol p-NA released/ml/h \\
A. Buffer & 22.6 \\
PBMC supernate + buffer & 11.9 \\
PBMC supernate + normal goat IgG & 9.9 \\
PBMC supernate + goat anti-Clq IgG & 9.2 \\
PBMC supernate + normal rabbit IgG & 9.2 \\
PBMC supernate + rabbit anti- $\beta_{2-}$ & \\
glycoprotein-I IgG & 10.6 \\
B. Buffer & 21.5 \\
PBMC supernate + buffer & 11.9 \\
PBMC supernate + normal goat IgG & 13.5 \\
PBMC supernate + goat anti-PF4 IgG & 14.7 \\
PBMC supernate + normal rabbit IgG & 12.9 \\
PBMC supernate + rabbit anti-Cī-INH & 14.1 \\
\hline
\end{tabular}

* In $12 \times 75 \mathrm{~mm}$ polystyrene tubes, $0.05 \mathrm{ml}$ PBMC supernate or DPBS (buffer) was incubated for $30 \mathrm{~min}$ at $37^{\circ} \mathrm{C}$ with $0.05 \mathrm{ml} \mathrm{IgG}$ or buffer, after which $0.1 \mathrm{ml} \mathrm{HF}(0.05 \mathrm{U} / \mathrm{ml})$ was added, followed, after $10 \mathrm{~min}$, by $0.05 \mathrm{ml}$ ellagic acid. The evolution of amidolytic activity was then determined as described in Methods. $(A)$ The specific activity of $\mathrm{HF}$ was $58 \mathrm{U} / \mathrm{mg}$ protein, the protein content of the PBMC supernate was $22 \mu \mathrm{g} / \mathrm{ml}$ and the initial concentration of ellagic acid was $2 \times 10^{-4} \mathrm{M}$. (B) The specific activity of $\mathrm{HF}$ was $43 \mathrm{U} / \mathrm{mg}$ protein, the protein content of the PBMC supernate was $15 \mu \mathrm{g} / \mathrm{ml}$, and the initial concentration of ellagic acid (of another lot) was 4 $\times 10^{-4} \mathrm{M}$. The initial protein concentration of IgG in $A$ was 2.2 $\mathrm{mg} / \mathrm{ml}$, and in $B, 1.2 \mathrm{mg} / \mathrm{ml}$. As described in Methods, the IgG fractions used in $A$ and $B$ were separated by different techniques. 
$\mathrm{Clq}$ and $\beta_{2}$-glycoprotein-I inhibit the activation of $\mathrm{HF}$ (32, 33). Neither of these proteins could be demonstrated in a concentrate of PBMC upon immunodiffusion against antisera against this protein. Further, a crude immunoglobulin fraction of these antiserums did not neutralize the inhibitory effect of PBMC supernates against the activation of HF (Table VII). At very high concentrations, PBMC supernates had some inhibitory activity against human urokinase-activated plasmin; a preparation of PBMC supernate $(508 \mu \mathrm{g}$ protein $/ \mathrm{ml})$ reduced the amidolytic activity of this enzyme from 37.0 to $29.4 \mathrm{nmol}$ $p$-NA released/ml per $\mathrm{h}$ by the method described.

Incubation of PBMC for $16 \mathrm{~h}$ with cycloheximide (50 $\mu \mathrm{g} / \mathrm{ml}$ ) sharply reduced the inhibitory properties of PBMC supernates, which contained strikingly less protein than the supernates of untreated cells, as though protein synthesis had been depressed (Table VIII). Similarly, PBMC treated with cycloheximide were less inhibitory than untreated cells, but the difference was less pronounced.

Incubation of PBMC overnight with sodium azide at a

Table VIII. Effect of Cycloheximide and Sodium Azide on the Inhibitory Properties of PBMC and Their Supernates

\begin{tabular}{lccccc}
\hline & \multicolumn{5}{c}{ Amidolysis* } \\
\cline { 2 - 6 } Test mixture dilution & PBMC & $\begin{array}{l}\text { Treated } \\
\text { PBMC }\end{array}$ & Supernate & $\begin{array}{l}\text { Treated } \\
\text { supernate }\end{array}$ & Buffer \\
\hline \multicolumn{5}{c}{ nmol p-NA released $/$ ml/h } \\
A. Cycloheximide & \multicolumn{5}{c}{} \\
Undilute & 2.9 & 1.6 & 0.3 & 14.3 & - \\
$1 / 2$ & 1.9 & 3.7 & 0.6 & 22.8 & - \\
$1 / 4$ & 1.4 & 15.8 & 2.1 & 25.6 & - \\
$1 / 8$ & 7.0 & 22.2 & 12.4 & 26.4 & - \\
$1 / 16$ & 18.4 & 24.4 & 22.5 & 24.4 & - \\
$\infty$ & - & - & - & - & 27.4 \\
B. Sodium azide & & & & & \\
Undilute & 2.1 & 1.1 & 0.3 & 9.9 & - \\
$1 / 2$ & 0.9 & 4.8 & 0.2 & 19.3 & - \\
$1 / 4$ & 0.9 & 18.3 & 0.8 & 22.3 & - \\
$1 / 8$ & 7.8 & 21.7 & 10.8 & 22.6 & - \\
$1 / 16$ & 16.9 & 22.6 & 20.6 & 22.9 & - \\
$\infty$ & - & - & - & - & 25.3 \\
& & & & & \\
\hline
\end{tabular}

In B, PBMC and sodium azide-treated PBMC and their supernates were prepared as described in Methods. Tested by trypan blue exclusion, the PBMC in the original suspension were $96 \%$ viable. After incubation for $20 \mathrm{~h}, \mathrm{PBMC}$ treated with sodium azide were $3 \%$ viable, and untreated PBMC were 92\% viable. The PBMC and their supernates were tested for their capacity to inhibit the activation of HF by ellagic acid as in Table I (see Methods). The protein content of the supernate of untreated cells was $78 \mu \mathrm{g} / \mathrm{ml}$; no protein was detected in the supernate of treated cells. The HF preparation used had a specific activity of $56 \mathrm{U} / \mathrm{mg}$ protein.

* In A, PBMC and cycloheximide-treated PBMC and their supernates were prepared as described in Methods. Tested by trypan blue exclusion, the PBMC in the original suspension were $91 \%$ viable. After incubation for $16 \mathrm{~h}, \mathrm{PBMC}$ treated with cycloheximide were $33 \%$ viable, and untreated PBMC were 50\% viable. The PBMC and their supernates were tested for their capacity to inhibit the activation of HF by ellagic acid as in Table I (see Methods). The protein content of the supernate of untreated cells was $77 \mu \mathrm{g} / \mathrm{ml}$, and of cycloheximide-treated cells, $10 \mu \mathrm{g} / \mathrm{ml}$. The HF preparation used had a specific activity of $58 \mathrm{U} / \mathrm{mg}$ protein. final concentration of $0.5 \mathrm{mg} / \mathrm{ml}$, sufficient to kill $97 \%$ of cells, greatly reduced the inhibitory properties of both the cells and the supernatant fluid, which now contained no detectable protein (Table VIII).

The inhibitory properties of PBMC or PBMC supernates for the activation of $\mathrm{HF}$ by glass and by sulfatides. Conceivably, in the experiments recorded thus far, inhibition of the activation of HF may have been due to a specific interaction between PBMC or PBMC supernatant fluid and ellagic acid. The same inhibitory characteristics were, however, demonstrable when activation of HF was carried out by exposure to glass (Table IX). Consistently, at higher dilutions, PBMC supernates enhanced amidolysis, a property not observed in the absence of HF. This enhancement of amidolysis was not blocked by treatment of the supernates with $1.0 \mathrm{mM}$ DFP (data not illustrated).

The plasmas of individuals with Hageman trait or plasma prekallikrein deficiency (Fletcher trait), and several ill-defined fractions or normal plasma, contain agents that adhere to glass and inhibit its capacity to initiate clotting $(24,34,35)$. PBMC supernates, however, did not appear to share this property. Coating glass tubes with the plasma of a patient with Hageman trait lengthened the partial thromboplastin time of normal plasma from $79.5 \mathrm{~s}$, tested in tubes coated with BS, to $107.8 \mathrm{~s}$. In contrast, the clotting time of tubes coated with PBMC supernatant fluid (15 $\mu \mathrm{g}$ protein $/ \mathrm{ml}$ ) was $74.8 \mathrm{~s}$.

Table IX. Effect of Peripheral Blood Mononuclear Supernates on the Activation of HF by Glass and Sulfatides

\begin{tabular}{|c|c|c|}
\hline \multirow{2}{*}{$\begin{array}{l}\text { PBMC supernate } \\
\text { dilution }\end{array}$} & \multicolumn{2}{|c|}{ Amidolysis } \\
\hline & Glass* & Sulfatides ${ }^{\ddagger}$ \\
\hline & \multicolumn{2}{|c|}{$n m o l p-N A$ released $/ m l / h$} \\
\hline Undilute & 2.0 & 1.3 \\
\hline $1 / 2$ & 8.1 & 1.3 \\
\hline $1 / 4$ & 13.8 & 12.6 \\
\hline $1 / 8$ & 12.8 & 27.8 \\
\hline$\infty$ & 10.9 & 31.0 \\
\hline$\infty^{\S}$ & 0.5 & - \\
\hline Undilute" & 11.3 & - \\
\hline
\end{tabular}

* Mixtures of $0.25 \mathrm{ml}$ each of a concentrate of PBMC supernate, diluted serially in DPBS, and $\mathrm{HF}(58 \mathrm{U} / \mathrm{mg}$ protein, $0.05 \mathrm{U} / \mathrm{ml}$ ) were prepared in $12 \times 75 \mathrm{~mm}$ polystyrene tubes. Aliquots of $0.2 \mathrm{ml}$ were transferred to $10 \times 75 \mathrm{~mm}$ glass tubes and incubated at $37^{\circ} \mathrm{C}$ for 60 min with continual shaking. Then, $0.1 \mathrm{ml}$ DPBS and $1.0 \mathrm{ml} \mathrm{HPPAN}$ were added to each tube and incubation was continued for an additional $60 \mathrm{~min}$. The reaction was stopped by addition of $0.3 \mathrm{ml}$ glacial acetic acid and the amount of $p$-NA that had been released was measured against suitable blanks to which glacial acetic acid had been added before HPPAN.

${ }^{\ddagger}$ In $12 \times 75 \mathrm{~mm}$ polystyrene tubes, $0.1 \mathrm{ml} \mathrm{HF}(0.05 \mathrm{U} / \mathrm{ml}, 56 \mathrm{u} / \mathrm{mg}$ protein) and $0.1 \mathrm{ml}$ PBMC supernate, serially diluted in DPBS, were incubated at $37^{\circ} \mathrm{C}$ for $10 \mathrm{~min}$. Thereafter, $0.05 \mathrm{ml} 3 \times 10^{-5} \mathrm{M}$ bovine brain sulfatides in BS was added, incubation was continued for $60 \mathrm{~min}, 1.0 \mathrm{ml} \mathrm{HPPAN}$ was added and amidolysis was measured as described in the preceding paragraph. The PBMC supernate had been concentrated by ultrafiltration and contained $163 \mu \mathrm{g}$ protein $/ \mathrm{ml}$. ${ }^{\S}$ Bovine albumin in BS substituted for HF in the original mixture.

" DPBS substituted for PBMC supernate in the original mixture and $0.1 \mathrm{ml} \mathrm{PBMC}$ supernate added to the mixture instead of DPBS after the first 60 -min incubation. 
Bovine brain sulfatides activate HF (2). The supernates of PBMC inhibited activation of HF by sulfatides, but only at higher protein concentrations than needed to inhibit ellagic acid (Table IX).

\section{Discussion}

A remarkable property of peripheral blood, much pondered in the nineteenth century, is that the circulating blood is fluid, yet clots promptly when it is withdrawn from blood vessels and transferred to glass tubes. One mechanism through which this comes about is the transformation of Hageman factor (HF, Factor XII) to an enzymatically active state upon contact with certain negatively charged agents (36). Equally remarkable is that the continual contact of plasma with biologically active blood cells does not initiated the clotting process. The experiments that have been described provide some clues to this puzzle, for suspensions of PBMC, including monocytes, lymphocytes (both T and B cells), neutrophils, and to a lesser extent platelets, all appeared to retard the activation of HF by ellagic acid, an agent that in apparent solution readily converts this clotting factor to its activated form. The supernatant fluids in which these cells were suspended shared this property, as if one or more inhibitors of the activation of HF were eluted from the cells. Indeed, since in this study the cells were necessarily suspended in an aqueous medium, it is possible that all of the results described were due to the presence of these inhibitory substances in the fluid phase.

Experiments were performed to determine whether the inhibitory properties of PBMC, monocytes, lymphocytes, and granulocytes were due to contamination with platelets. Preparing PBMC from the blood of a patient with aplastic anemia did not alter the result, nor did partial reduction of the platelet contamination of preparations of PBMC, lymphocytes, and granulocytes. Moreover, supernates of cultured monocytoid cells, uncontaminated with platelets, inhibited activation of HF by ellagic acid.

The nature of the inhibitory agent or agents eluted from cells was only poorly defined. Several lines of evidence suggest that the inhibitory property was related to protein substances in the supernates of cell suspensions. Thus, the inhibitory activity was heat labile, precipitable by ammonium sulfate, and diminished by treatment of cells or supernate with trypsin, or by incubating cells overnight with cycloheximide, an inhibitor of protein synthesis. That the inhibitory property was of cellular origin was further demonstrated by testing the cytosol and particulate fractions of PBMC, monocytes and lymphocytes, both of which blocked the activation of HF by ellagic acid. No evidence was obtained suggesting that inhibition of the activation of HF was enzymatic, nor could we demonstrate binding of $\mathrm{HF}$ to insolubilized PBMC supernates.

The inhibitory properties of PBMC supernates appeared to be relatively specifically directed against the activation of HF. The preparations tested did not inhibit the kaolin-activated partial thromboplastin time or the prothrombin time of normal plasma, and did not inhibit thrombin or the activated forms of Stuart factor (Factor Xa), PTA (Factor XIa) or the first component of complement ( $\mathrm{C} \overline{1}$ of $\mathrm{C} 1$ esterase). At very high concentrations, PBMC supernates partially inhibited the amidolytic properties of human plasmin.

Some years ago, the plasma of patients with Hageman trait or with hereditary deficiency of plasma prekallikrein (Fletcher trait) was found to contain agents that were adsorbed to a glass surface, where they reduced the clot-promoting properties of glass $(34,35)$. Similar agents were also demonstrated in fractions of normal plasma (24). We were, however, unable to demonstrate that the inhibitory properties of PBMC supernates were adsorbed to glass surfaces, suggesting that the supernates contained an agent or agents different from those found in human plasma. Two specific protein components of plasma that inhibit the activation of HF have been identified, $\beta_{2}$-glycoprotein-I (32) and C1q (33). Although this might suggest that the inhibitory property of blood cells may have been due to the selective adsorption of these plasma agents to the cell surface, this did not appear to be the case, for we were unable to demonstrate their presence in concentrates of PBMC supernates by immunodiffusion studies against specific antisera. Another plasma protein, $\mathrm{C} \overline{1}$ inhibitor (Cî-INH), inhibits activated HF (37), whereas PBMC supernates appeared to inhibit the activation of this clotting factor; the presence of Cí-INH in PBMC supernates could not be demonstrated either functionally or by immunodiffusion against specific antiserum.

Cell walls are rich in proteoglycans. It is unlikely that the presence of these substances in PBMC supernates was responsible for their inhibitory effects, since proteoglycans and their constituent glycosaminoglycans are activators, rather than inhibitors of Hageman factor $(38,39)$. No uronic acid could be demonstrated in concentrates of PBMC supernates, but this does not exclude the possibility that proteoglycans not containing uronic acid were present.

Because the preparations of PBMC studied were contaminated with platelets, the possibility that the phenomena observed were due to PF4 was of interest. PF4 is known to block activation of the contact system (40). Although we confirmed this observation, we could not demonstrate the presence of PF4 in concentrates of PBMC supernates immunologically, and the addition of heparin to PBMC supernates did not block their inhibitory properties.

The inhibitory activity of PBMC was a property of viable cells, for it was greatly diminished by incubating these cells overnight in sodium azide, a procedure that appeared to kill all but a few cells. Thus, it seems unlikely that the observations recorded were due to the adsorption of plasma proteins to the cell surface.

The question emerged whether the observations reported were due to a specific reaction between cell suspensions or the supernates of these suspensions and ellagic acid. Similar results were obtained, however, when glass or bovine brain sulfatides were used to activate $\mathrm{HF}$.

The supernatants of PBMC, granulocytes, and platelets studied were crude, and presumably contained many different agents. We have not yet been able to assign the inhibitory property of peripheral blood cells to any of their known components, but experiments to this end are in progress. Whether the properties observed are intrinsic to other cells is also not known, but preliminary experiments suggest that similar inhibitory activity is present in the conditioned media in which bovine arterial endothelial cells have been cultured.

The experiments described suggest that intravascular coagulation is impeded by metabolically active cells with which the plasma of peripheral blood comes in contact. Whether these observations reflect significant mechanisms for maintaining the fluidity of circulating blood remains to be elucidated. 


\section{Acknowledgments}

The patient with aplastic anemia was studied through the courtesy of Dr. E. M. Gordon, Rainbow Babies and Childrens Hospital, Cleveland, OH. Dr. Charles J. Malemud and Mr. Robert Papay assayed PBMC supernates for uronic acid. We are indebted to Dr. Malemud and to Dr. Lloyd A. Culp for advice concerning proteoglycans and PF4.

This study was supported in part by grant HL 01661 from the National Heart, Lung and Blood Institute, the National Institutes of Health, U. S. Public Health Service, and in part by grants from the American Heart Association and its Northeast Ohio affiliate. Dr. Ratnoff is a Career Investigator of the American Heart Association. The participation of Dr. Nicholas P. Ziats was made possible by funds from the Institute of Pathology, Case Western Reserve University.

\section{References}

1. Zimmerman, T. S., O. D. Ratnoff, and A. E. Powell. 1971. Immunologic differentiation of classic hemophilia (Factor VIII deficiency) and von Willebrand's disease with observations on combined deficiencies of antihemophilic factor and proaccelerin (Factor $V$ ) and on an acquired circulating anticoagulant against antihemophilic factor. J. Clin. Invest. 50:244-254.

2. España, F., and O. D. Ratnoff. 1983. Activation of Hageman factor (factor XII) by sulfatides and other agents in the absence of plasma proteases. J. Lab. Clin. Med. 102:31-45.

3. Ratnoff, O. D., B. Everson, V. H. Donaldson, and B. H. Mitchell. 1986. Purification of Hageman factor (Factor XII) on columns of popcorn-agarose. Blood. 67:1550-1553.

4. Svendsen, L., B. Blombäck, M. Blombäck, and P. I. Olsson. 1972. Synthetic chromogenic substrates for determination of trypsin, thrombin and thrombin-like enzymes. Thromb. Res. 1:267-278.

5. Dulbecco, R., and M. Vogt. 1954. Plaque formation and isolation of pure lines with poliomyelitis virus. J. Exp. Med. 99:167-182.

6. Moore, G. E., R. E. Gerner, and H. A. Franklin. 1967. Culture of normal human leukocytes. JAMA (J. Am. Med. Assoc.). 199:519-524.

7. Steinbuch, M., and R. Audran. 1969. The isolation of IgG from mammalian sera with the aid of caprylic acid. Arch. Biochem. Biophysiol. 134:279-284.

8. Ratnoff, O. D. 1972. Studies on the product of the reaction between activated Hageman factor (factor XII) and plasma thromboplastin antecedent (factor XI). J. Lab. Clin. Med. 80:704-710.

9. Di Scipio, M. A., and E. W. Davie. 1977. Activation of human factor X (Stuart factor) by a protease from Russell's viper venom. Biochem. 16:5253-5260.

10. Saito, H., O. D. Ratnoff, J. S. Marshall, and J. Pensky. 1973. Partial purification of plasma thromboplastin antecedent (factor XI) and its activation by trypsin. J. Clin. Invest. 51:850-861.

11. Lark, M. W., and L. A. Culp. 1984. Multiple classes of heparan sulfate proteoglycans from fibroblast substratum adhesion sites. $J$. Biol. Chem. 259:6773-6782.

12. Donaldson, V. H. 1966. Serum inhibitor of $C^{\prime} 1$-esterase in health and disease. J. Lab. Clin. Med. 68:382.

13. Böyum, A. 1968. Isolation of mononuclear cells and granulocytes from human blood. Scand. J. Clin. Lab. Invest. 21 (Suppl. 97):77-89.

14. Teitz, N. 1976. Fundamentals of Clinical Chemistry. W. B. Saunders, Philadelphia. 653-655.

15. Hudson, L., and F. C. Hay. 1980. Practical Immunology. 2nd ed. Blackwell Scientific Publications, Oxford.

16. Bitter, T., and H. M. Muir. 1962. A modified uronic acid carbazole reaction. Anal. Biochem. 4:330-334.

17. Fischer, D. G., and H. S. Koren. 1981. Isolation of human monocytes. In Methods for Studying Monocuclear Phagocytes. D. O. Adams, P. J. Edelson, and H. S. Koren, editors. Academic Press, New York. 43-47.

18. Sundstrom, C., and K. Nilsson. 1976. Establishment and char- acterization of a human histiocytic lymphoma line (U937). Int. J. Cancer. 17:567-577.

19. Greaves, M. F., and G. Brown. 1974. Purification of human T and B lymphocytes. J. Immunol. 112:420-423.

20. Weiner, M. S., C. Bianco, and V. Nussensweig. 1973. Enhanced binding of neuraminidase-treated sheep erythrocytes to human $T$ lymphocytes. Blood. 42:939-946.

21. Lederman, M. M., O. D. Ratnoff, J. J. Scillian, P. K. Jones, and B. Schacter. 1983. Impaired cell-mediated immunity in patients with classic hemophilia. N. Engl. J. Med. 308:79-83.

22. Spagnuola, P. J., J. J. Ellner, A. Hassid, and M. J. Dunn. 1980. Thromboxane $A_{2}$ mediates augmented polymorphonuclear leukocyte adhesiveness. J. Clin. Invest. 66:406-414.

23. Kinlough-Rathbone, R. L., J. F. Mustard, M. A. Packham, D. W. Perry, H.-J. Reimers, and J. P. Cazenave. 1977. Properties of washed human platelets. Thromb. Haemostasis. 37:291-308.

24. Saito, H., O. D. Ratnoff, V. H. Donaldson, G. Haney, and J. Pensky. 1974. Inhibition of the adsorption of Hageman factor (factor XII) to glass by normal human plasma. J. Lab. Clin. Med. 84:62-73.

25. Ratnoff, O. D., and H. L. Nossel. 1983. Wasp sting anaphylaxis. Blood. 61:132-139.

26. Chediak, J., P. Madej-Zevin, O. D. Ratnoff, G. H. Goldsmith, Jr., and B. Everson. 1986. Studies on a circulating anticoagulant inhibiting factor XI in a patient with congenital deficiency and carcinoma of the prostate. Br. J. Haematol. 63:123-133.

27. Levy, L. R., and I. H. Lepow. 1959. Assay and properties of serum inhibitor of C'1 esterase. Proc. Soc. Exp. Biol. Med. 101:608611.

28. Ødegard, O. R., M. Lie, and U. Abildgaard. 1976. Antifactor $\mathrm{Xa}$ activity measured with amidolytic methods. Hemostasis. 5:265275.

29. Phillips, H. J. 1973. Dye exclusion tests for cell viability. In Tissue Culture Methods and Application. P. K. Kruse and M. K. Patterson, Jr., editor. Academic Press, New York. 406-408.

30. Lowry, O. H., N. J. Rosebrough, A. L. Farr, and R. J. Randall. 1951. Protein measurement with the Folin phenol reagent. J. Biol. Chem. 193:265-275.

31. Ratnoff, O. D. 1981. Studies on the inhibition of ellagic acidactivated Hageman factor (Factor XII) and Hageman factor fragments. Blood. 57:55-58.

32. Schousboe, I. 1985. $\beta_{2}$-Glycoprotein I: A plasma inhibitor of the contact activation of the intrinsic blood coagulation pathway. Blood. 66:1086-1901.

33. Rehmus, E. H., B. M. Greene, O. D. Ratnoff, and B. B. Everson. 1987. Inhibition of the activation of Hageman factor (Factor XIIa) by complement component Clq. J. Clin. Invest. 80:516-521.

34. Ratnoff, O. D., and J. M. Rosenblum. 1958. Role of Hageman factor in the initiation of clotting by glass. Evidence that glass frees Hageman factor from inhibition. Am. J. Med. 25:160-168.

35. Saito, H., O. D. Ratnoff, V. H. Donaldson, C. C. Abildgaard, and P. G. Hattersley. 1972. Letter to the editor. Blood. 39:745-747.

36. Ratnoff, O. D. 1985. The legacy of John Hageman: New dividends. Trans. Assoc. Am. Physiol. 98:cli-clxi.

37. Forbes, C. D., J. Pensky, and O. D. Ratnoff. 1970. Inhibition of activated Hageman factor and activated plasma thromboplastin antecedent by purified serum $\mathrm{Cl}$ inactivator. J. Lab. Clin. Med. 76:809815.

38. Moskowitz, R. W., H. J. Schwartz, B. Michel, O. D. Ratnoff, and T. Astrup. 1970. Generation of kinin-like agents by chondroitin sulfate, heparin, chitin sulfate and human articular cartilage: Possible pathophysiologic implications. J. Lab. Clin. Med. 76:790-798.

39. Hojima, Y., C. G. Cochrane, R. C. Wiggins, K. F. Austen, and R. L. Stevens. 1984. In vitro activation of the contact (Hageman factor) system of plasma by heparin and chondroitin sulfate E. Blood. 63:1453-1459.

40. Scully, M. F., K. Weerasinghe, and V. V. Kakkar. 1980. Inhibition of contact activation by platelet factor 4. Thromb. Res. 20:461466. 